EXTENDED REPORT

\title{
No evidence for involvement of the Toll-like receptor 4 (TLR4) A896G and CD14-C260T polymorphisms in susceptibility to ankylosing spondylitis
}

\author{
M van der Paardt, J B A Crusius, M H M T de Koning, S A Morré, R J van de Stadt, B A C Dijkmans, \\ A S Peña, I E van der Horst-Bruinsma
}

See end of article for authors' affiliations

Correspondence to:

Dr I E van der Horst-

Bruinsma, VU University

Medical Centre,

Department of

Rheumatology, Room 4A-

42, PO Box 7057, 1007

$M B$ Amsterdam, the

Netherlands; secr.

reumatologie@vumc.nl

Accepted 20 June 2004

\begin{abstract}
Objectives: Ankylosing spondylitis (AS) is a multifactorial and polygenic disease. Apart from HLA, other genes very probably play a role in disease susceptibility. Indigenous bacteria of the gastrointestinal flora appear to play a role in the pathogenesis of the disease; therefore, genes controling the innate and acquired immune response are good candidates to study disease susceptibility. CD14 and Toll-like receptor 4 (TLR4) are key receptors for the sensing of bacteria. The CD14 C-260T and TLR4 A896G single nucleotide polymorphims are associated with aberrant signal transduction for bacterial agonists.

Methods: The distribution of the CD14 C-260T and TLR4 A896G polymorphisms was studied in genomic DNA from 113 unrelated white Dutch AS patients and 170 ethnically matched healthy controls. The diagnosis of AS was made according to the modified New York criteria. The CDI4 C-260T and TLR4 A896G polymorphisms were genotyped by PCR-RFLP methods.

Results: No significant differences were found between patients and controls in the frequencies of the carriership of the less frequent CD14-260T allele (odds ratio $0.65 ; 95 \%$ confidence interval 0.37 to 1.15 ) or the TLR4 $896 \mathrm{G}$ allele (1.68; 0.67 to 4.19$)$.

Conclusions: There is no evidence for involvement of the CD14 C-260T or TLR4 A896G polymorphisms in susceptibility to AS. An important role of bacteria and genetic predisposition of the innate immune system in cases of AS cannot be excluded by these findings. Therefore, studies of the surprisingly highly polymorphic candidate genes in this field should be continued.
\end{abstract}

macrophages for complexes of LPS and LPS binding protein (LBP). ${ }^{6}$ LPS is transferred from a CD14/LBP complex to a TLR4/MD-2 membrane receptor complex at the cell surface. ${ }^{7}$ A transmembrane signal leads to nuclear factor $(\mathrm{NF})-\kappa \mathrm{B}$ activation, subsequent induction of gene transcription and release of pro-inflammatory cytokines, such as tumour necrosis factor $\alpha$, initiating inflammation. ${ }^{8}$

Besides LPS, other bacterial and host agonists are reported to be recognised by TLR4 including C. trachomatis and host heat shock protein 60 (HSP60) ligands. ${ }^{9}$

Although, to the best of our knowledge there is no evidence for linkage in the region of the CD14-260 single nucleotide polymorphism (SNP) on chromosome 5q31, functional studies imply this gene may be of relevance to AS. The CD14-260 promoter SNP enhances transcriptional activity, ${ }^{10}$ and is associated with enhanced monocyte CDI4 expression. ${ }^{11}{ }^{12}$ Individuals carrying the TT genotype have significantly higher serum levels of soluble CD14 than have those with CC or CT genotypes and they have increased density of CD14 in blood monocytes. ${ }^{11} 12$

Recently, allele CD14-260T has been found to be significantly positively associated with ulcerative colitis (UC) in Japan. ${ }^{13}$ However, in Germany, the allele CD14-260T and the genotype TT were increased in Crohn's disease (CD) but not in UC. ${ }^{14}$ More recently, the same group of investigators found allele CD14-260T and TT genotype frequencies of the CD14 SNP to be significantly increased only in patients with CD carrying at least one of the susceptibility variants Arg702Trp,

Abbreviations: AS, ankylosing spondylitis; $C D$, Crohn's disease; HSP, heat shock protein; LBP, lipopolysaccharide binding protein; LPS, lipopolysaccharide; NF, nuclear factor; SNP, single nucleotide polymorphism; TLR, Toll-like receptor; UC, ulcerative colitis 
Gly908Arg, or Leul007fsinsC in the CARD 15 gene..$^{15}$ Both UC and $\mathrm{CD}$ can have disease manifestations that belong to the spondylarthropathies.

So far, there have been no studies addressing the possible association of the CD14-C260T SNP with AS, although carriage of the CD14-260T allele might increase the susceptibility of female patients to the development of chronic spondylarthropathy. ${ }^{16}$

The TLR4 gene is located on chromosome 9q32-q33 at $115.8 \mathrm{Mb}$. Genome scanning in AS identified linkage to a region on chromosome 9q. Marker D9S1826 on chromosome $9 \mathrm{q} 34$ at $133.9 \mathrm{Mb}$ achieved a lod score of $2.8(\mathrm{p}<0.0005)$, and marker D9S1682 at $120.4 \mathrm{Mb}$ achieved a lod score of 2.3 $(\mathrm{p}<0.005)$, both suggestive of linkage. ${ }^{17}$ Given the distance between the TLR4 gene and the D9S1826 and D9S1682 markers, it is unlikely that TLR4 can warrant the linkage to the region on chromosome 9. Nevertheless, similar to the situation in CD14, functional studies imply that TLR4 might be of relevance to AS.

The A896G SNP is located in the ectoplasmic receptor domain of TLR4, resulting in an aspartic acid to glycine substitution at position 299. Recently, the A896G SNP was shown to be associated with "an endotoxin hyporesponsive phenotype" in concert with other genetic changes or acquired factors that influence the complex physiological response to LPS. ${ }^{18}$ However, monocytes from individuals heterozygous for allele TLR4 896G do not exhibit a deficit in recognition of LPS from several bacterial strains. ${ }^{19}$ Moreover, the heterozygous TLR4 A896G polymorphism does not influence LPS induced human whole blood cytokine release $e^{20}$. Other agonists for TLR4 have not yet been tested functionally.

The present study was designed to study the frequency of the CD14 C-260T and TLR4 A896G SNPs in AS to find out whether these polymorphisms contribute to disease susceptibility and clinical manifestations.

\section{PATIENTS AND METHODS \\ Subjects}

After informed consent, 113 AS patients were recruited from the outpatient Department of Rheumatology of the Jan van Breemen Institute. All AS patients fulfilled the diagnosis of AS, according to the modified New York criteria. ${ }^{21}$ Controls were 170 randomly selected healthy blood donors from the Amsterdam region. All subjects were unrelated Dutch whites.

\section{Methods}

Genotyping the CD14 C-260T SNP (NCBI SNP cluster ID: rs2569190) was performed with forward primer 5'-TCACC TCCCCACCTCTCTT- $3^{\prime}$ and 5'-CCTGCAGAAT_CCTTCCTGTT3'. Digestion overnight with HaeIII (New England Biolabs, $\mathrm{UK}$ ) of the $107 \mathrm{bp}$ amplicons was followed by separation by

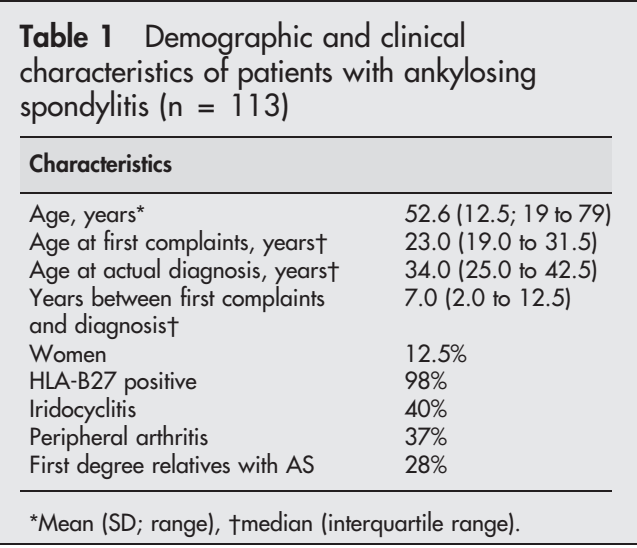

electrophoresis on $4 \%$ agarose gels, staining with ethidium bromide, and visualisation under ultraviolet light, and resulted in two fragments of 83 and $24 \mathrm{bp}$ (C allele) or $107 \mathrm{bp}$ (T allele).

Genotyping of the TLR4 A896G SNP (NCBI SNP cluster ID: rs4986790) was performed as described by Morré et al..$^{22}$

\section{Statistical analysis}

Allele and genotype frequencies were tested for HardyWeinberg equilibrium by $\chi^{2}$ test. To compare frequencies, $\chi^{2}$ or Fisher's exact test was used. The possible influence of interaction of the two studied polymorphisms in patients and controls was analysed by logistic regression. A two sided $p$ value $<0.05$ was considered significant. The magnitude of association was expressed as odds ratio with a 95\% confidence interval (CI). Statistical analysis was performed by SPSS 10.0 for Windows.

\section{RESULTS}

Characteristics of the 113 AS patients are summarised in table 1. Genotype and allele frequencies in AS patients and controls for the CD14 C-260T and the TLR4 A896G SNP in table 2 . The genotype frequencies in the control group did not deviate from HWE equilibrium. No significant differences were observed between AS patients and controls in the frequencies of carriership of the CD14-260T and TLR4 896G alleles (table 2). Logistic regression analysis showed absence of modification of the odds ratios (OR). Thus, no interaction between the CD14 C-260T and TLR4 A896G polymorphisms was found (data not shown).

No significant associations were found between carriage of each of the alleles CDI4-260T and TLR4 896G with sex, existence in past or present of peripheral arthritis or acute anterior uveitis, age at first complaints, years between first complaints and actual diagnosis of AS, or the number of patients with at least one first degree family member with AS (table 3).

\section{DISCUSSION}

The studied SNPs reported to affect gene function in two genes that play a role in innate immunity, CD14 C-260T and TLR4 A896G, are not significantly associated with the susceptibility to or the clinical manifestations of AS.

Table 2 Allele and genotype frequencies of the CD14 C$260 T$ and the TLR4 A896G polymorphisms in ankylosing spondylitis patients and controls

\begin{tabular}{|c|c|c|c|c|}
\hline & $\begin{array}{l}\text { AS patients } \\
(n=113)\end{array}$ & $\begin{array}{l}\text { Controls } \\
(n=170)\end{array}$ & & $\mathbf{p}$ \\
\hline \multicolumn{5}{|c|}{ CDI4 C-260T } \\
\hline \multicolumn{5}{|c|}{ Allele } \\
\hline C & 111 (49.1\%) & $178(52.4 \%)$ & $\mathrm{OR}=0.88$ & 0.45 \\
\hline $\mathrm{T}$ & 115 (50.9\%) & $162(47.6 \%)$ & $\begin{array}{l}95 \% \mathrm{Cl}= \\
0.63 \text { to } 1.23\end{array}$ & \\
\hline \multicolumn{5}{|c|}{ Genotype } \\
\hline CC & $23(20.4 \%)$ & $48(28.2 \%)$ & $\chi^{2}=2.87$ & 0.24 \\
\hline $\mathrm{CT}$ & $65(57.5 \%)$ & $82(48.2 \%)$ & & \\
\hline Tा & $25(22.1 \%)$ & $40(23.5 \%)$ & & \\
\hline \multicolumn{5}{|c|}{ TLR4 A896G } \\
\hline A & $219(96.9 \%)$ & 322 (94.7\%) & $\mathrm{OR}=1.75$ & 0.21 \\
\hline G & $7(3.1 \%)$ & $18(5.3 \%)$ & $\begin{array}{l}95 \% \mathrm{Cl}= \\
0.72 \text { to } 4.26\end{array}$ & \\
\hline \multicolumn{5}{|c|}{ Genotype } \\
\hline $\mathrm{AA}$ & 106 (93.8\%) & $153(90.0 \%)$ & $\chi^{2}=1.64$ & 0.44 \\
\hline$A G$ & $7(6.2 \%)$ & $16(9.4 \%)$ & & \\
\hline GG & $0(0 \%)$ & $1(0.6 \%)$ & & \\
\hline
\end{tabular}

No significant difference was found between patients and controls in the frequencies of the carriership of the CD14-260T (OR $0.65 ; 95 \% \mathrm{CI} 0.37$ to 1.15 ) or TLR4 896G (OR 1.68; $95 \% \mathrm{Cl} 0.67$ to 4.19 ) allele. 
Table 3 Clinical characteristics of patients with ankylosing spondylitis $(n=113)$ in relation to carriage of the CD14-260T or the TLR4 896G allele

\begin{tabular}{|c|c|c|c|c|c|c|c|c|}
\hline \multirow[b]{2}{*}{ Characteristics } & \multicolumn{4}{|l|}{ TLR4 896G } & \multicolumn{4}{|l|}{ CD14 260T } \\
\hline & Carrier & Non-carrier & OR $(95 \% \mathrm{Cl})$ & $\mathbf{p}$ & Carrier & $\begin{array}{l}\text { Non- } \\
\text { carrier }\end{array}$ & OR $(95 \% \mathrm{Cl})$ & $\mathbf{p}$ \\
\hline Female/male & $1 / 6$ & $12 / 85$ & $\begin{array}{l}1.18 \\
(0.13 \text { to } 10.67)\end{array}$ & 1.0 & $11 / 72$ & $2 / 19$ & $\begin{array}{l}1.45 \\
(0.30 \text { to } 7.11)\end{array}$ & 1.0 \\
\hline PA $(+/-)$ & $3 / 4$ & $35 / 60$ & $\begin{array}{l}0.78 \\
(0.16 \text { to } 3.68)\end{array}$ & 1.0 & $33 / 48$ & $5 / 16$ & $\begin{array}{l}0.46 \\
(0.15 \text { to } 1.36)\end{array}$ & 0.15 \\
\hline $\mathrm{AAU}(+/-)$ & $5 / 2$ & $34 / 57$ & $\begin{array}{l}0.24 \\
(0.04 \text { to } 1.30)\end{array}$ & 0.11 & $31 / 48$ & $8 / 11$ & $\begin{array}{l}1.13 \\
(0.41 \text { to } 3.11)\end{array}$ & 0.82 \\
\hline Familial(+/-) & $2 / 4$ & $23 / 61$ & $\begin{array}{l}0.75 \\
(0.13 \text { to } 4.40)\end{array}$ & 0.67 & $21 / 51$ & $4 / 14$ & $\begin{array}{l}0.69 \\
(0.20 \text { to } 2.36)\end{array}$ & 0.56 \\
\hline $\begin{array}{l}\text { Age at first } \\
\text { complaints, mean } \\
\text { (SD) (range) }\end{array}$ & $\begin{array}{l}23.83(6.18) \\
(18 \text { to } 32)\end{array}$ & $\begin{array}{l}25.64(9.78) \\
(9 \text { to } 55)\end{array}$ & & $0.57^{*}$ & $\begin{array}{l}25.17(9.39) \\
(9 \text { to } 51)\end{array}$ & $\begin{array}{l}25.89(10.37) \\
(16 \text { to } 55)\end{array}$ & & $0.63^{*}$ \\
\hline $\begin{array}{l}\text { Years to actual } \\
\text { diagnosis, mean } \\
\text { (SD) (range) }\end{array}$ & $\begin{array}{l}9.08(11.43) \\
(1 \text { to } 32)\end{array}$ & $\begin{array}{l}9.27(8.83) \\
(1 \text { to } 40)\end{array}$ & & $0.77^{*}$ & $\begin{array}{l}8.99(8.79) \\
(1 \text { to } 37)\end{array}$ & $\begin{array}{l}10.33(9.74) \\
(1 \text { to } 40)\end{array}$ & & $0.43^{*}$ \\
\hline
\end{tabular}

Nevertheless, this study cannot exclude that specific phenotypic features of AS are related to TLR4 and/or CDI4 genotypes. Therefore, it would be of interest to assess whether the CD14 C-260T and TLR4 A896G SNPs are associated with disease severity (C-reactive protein, ESR, Bath Ankylosing Spondylitis Disease Activity Index, Bath Ankylosing Spondylitis Functional Index), anatomical evolution (Bath Ankylosing Spondylitis Metrology Index, sacroiliitis, degree of ankylosis), or involvement of the gut. Moreover, although this study could not find a significant association between CD14 C-260T and TLR4 A896G and the clinical manifestations of AS, the number of patients in this analysis was too low to warrant a definitive conclusion.

Bacteria are thought to play a crucial role in the pathogenesis of AS. In animal models such as B27 transgenic rats, in $\sim 50 \%$ of the cases, the presence of the bacterial flora is obligatory for development of inflammatory gut lesions and peripheral and axial inflammatory joint lesions, similar to AS. When raised in a germfree environment, inflammatory intestinal or joint disease does not develop until the normal bacterial flora is restored. ${ }^{23}$

AS occurs frequently in patients with newly diagnosed inflammatory bowel disease-that is, UC or CD. ${ }^{24}$ On the other hand, patients with spondylarthropathies often have subclinical gut involvement. ${ }^{25}$ This gut inflammation is clinically and histologically closely related to CD. ${ }^{26} 27$

It is likely that an altered host response of the innate immune system may contribute to the development of AS. This hypothesis is supported by the findings on genetic susceptibility of $C D$, which have shifted the focus of research in this disease towards innate immunity. The relationship with acquired immunity provides a good insight into the mechanisms that control inflammation in the gut. ${ }^{28}$ Recently, IgA levels of anti-Saccharomyces cerevisiae mannan antibodies, a marker of CD, have been found to be significantly higher in patients with spondylarthropathies, and more specifically in AS, than in healthy controls and patients with rheumatoid arthritis. $^{29}$

Besides the association reported with $C D 14,{ }^{15}$ an established genetic association of the innate immune system with CD is the Leul007fsinsC insertion mutation at position 3020 in the CARD15 gene, located on chromosome 16p12. This mutation was described as an important susceptibility factor for CD. ${ }^{30-33}$ However, studies from our group in the Netherlands, ${ }^{34}$ and from Spain ${ }^{35}$ and the $\mathrm{UK}^{36}$ have disproved that the commonest CARD15 mutations found in these populations contribute to the disease susceptibility in primary AS.

The identification and functional characterisation of mutants, such as those in CD14, TLR, and NOD2/CARD15 receptors, provide a new insight into the relationships between bacteria and the host, and between bacteria and the development of disease. ${ }^{37}{ }^{38}$ A previous study in Germany in a population of similar ethnic background to the one we have studied has revealed interactions of the CARD15 and CD14 genes that increase the risk for developing CD. ${ }^{15}$ Interestingly, so far the associations found in the three genes CD14, CARD15, and TLR4 have not been reproduced in all population studies demonstrating the complexity of the interaction between genes and environment. As recently described by Vercelli, " "Genetic variation in innate immunity genes at the interface with the environment may skew the human immune response in critical ways by modulating the impact of pathogen exposure". Therefore, although we found no significant associations between the CD14-C260T and TLR4 A896G SNPs with AS in general or with clinical characteristics, the significance of functional polymorphisms in genes that are involved in innate immunity deserve to be studied in this disease, in which bacteria and HLA appear to be important in the pathogenesis.

These are early days in the studies of innate immunity in AS and in many other chronic inflammatory diseases. It is possible that polymorphisms in other receptors sensing other bacteria than the ones recognised by CDI4, TLR4, and CARD15 may prove to be important in understanding the synergy between clinical manifestations, epidemiology, molecular biology, and pathophysiology of inflammation.

\section{ACKNOWLEDGEMENTS}

The authors are grateful to J Pleijster for assistance in genotyping the CD14 C-260T and TLR4 A896G polymorphisms.

\section{Authors' affiliations}

M van der Paardt, M H M T de Koning, R J van de Stadt, B A C Dijkmans, The Jan van Breemen Institute

J B A Crusius, S A Morré, A S Peña, the Laboratory of Immunogenetics A S Peña, the Department of Gastroenterology

B A C Dijkmans, I E van der Horst-Bruinsma, and the Department of Rheumatology, VU University Medical Centre, Amsterdam, the Netherlands 


\section{REFERENCES}

1 Brewerton DA, Hart FD, Nicholls A, Caffrey M, James DC, Sturrock RD. Ankylosing spondylitis and HL-A 27. Lancet 1973:904-7.

2 Schlosstein L, Terasaki PI, Bluestone R, Pearson CM. High association of an $\mathrm{HL}-\mathrm{A}$ antigen, W27, with ankylosing spondylitis. N Engl J Med 1973;288:704-6.

3 Burmester GR, Daser A, Kamradt T, Krause A, Mitchison NA, Sieper J, et al. Immunology of reactive arthritides. Annu Rev Immunol 1995; 13:229-50.

4 Zeidler HK, Schumacher HR. Chlamydia-induced arthritis. In: Calin A, Taurog JD, eds. The spondylarthritides, 1 st ed. Oxford: Oxford University Press, 1998:69-96.

5 van der Paardt $M$, van Denderen JC, van den Brule AJ, Morré SA, van der Horst-Bruinsma IE, Bezemer PD, et al. Prevalence of Chlamydia trachomatis in urine of male patients with ankylosing spondylitis is not increased. Ann Rheum Dis 2000;59:300-2

6 Wright SD, Ramos RA, Tobias PS, Ulevitch RJ, Mathison JC. CD14, a receptor for complexes of lipopolysaccharide (LPS) and LPS binding protein. Science 1990;249:1431-3

7 da Silva Correia J, Soldau K, Christen U, Tobias PS, Ulevitch RJ. Lipopolysaccharide is in close proximity to each of the proteins in its membrane receptor complex. Transfer from CD14 to TLR4 and MD-2. J Biol Chem 2001;276:21129-35.

8 Chow JC, Young DW, Golenbock DT, Christ WJ, Gusovsky F. Toll-like receptor-4 mediates lipopolysaccharide-induced signal transduction. J Biol Chem 1999:274:10689-92.

9 Vabulas RM, Ahmad-Nejad P, da Costa C, Miethke T, Kirschning CJ, Hacker H, et al. Endocytosed HSP60s use toll-like receptor 2 (TLR2) and TLR4 to activate the toll/interleukin-1 receptor signaling pathway in innate immune cells. J Biol Chem 2001;276:31332-9.

10 LeVan TD, Bloom JW, Bailey TJ, Karp CL, Halonen M, Martinez FD, et al. A common single nucleotide polymorphism in the CD14 promoter decreases the affinity of Sp protein binding and enhances transcriptional activity. J Immunol 2001;167:5838-44

11 Baldini M, Lohman IC, Halonen M, Erickson RP, Holt PG, Martinez FD. A polymorphism in the $5^{\prime}$ flanking region of the CDI4 gene is associated with circulating soluble CD14 levels and with total serum immunoglobulin $\mathrm{E}$ Am J Respir Cell Mol Biol 1999:20:976-83.

12 Hubacek JA, Rothe G, Pit'ha J, Skodova Z, Stanek V, Poledne R, et al. G. C($260) \rightarrow$ T polymorphism in the promoter of the CDI 4 monocyte receptor gene as a risk factor for myocardial infarction. Circulation 1999;99:3218-20.

13 Obana N, Takahashi S, Kinouchi Y, Negoro K, Takagi S, Hiwatashi N, et al. Ulcerative colitis is associated with a promoter polymorphism of lipopolysaccharide receptor gene, CD14. Scand J Gastroenterol 2002;37:699-704.

14 Klein W, Tromm A, Griga T, Fricke H, Folwaczny C, Hocke M, et al. A polymorphism in the CD14 gene is associated with Crohn disease. Scand J Gastroenterol 2002;37:189-91.

15 Klein W, Tromm A, Griga T, Folwaczny C, Hocke M, Eitner K, et al. Interaction of polymorphisms in the CARD1 5 and CDI 4 genes in patients with Crohn disease. Scand J Gastroenterol 2003;38:834-6.

16 Repo H, Anttonen K, Kilpinen SK, Palotie A, Salven P, Orpana A, et al. CD14 and TNF $\alpha$ promoter polymorphisms in patients with acute arthritis. Special reference to development of chronic spondyloarthropathy. Scand J Rheumatol 2002;31:355-61.

17 Laval SH, Timms A, Edwards S, Bradbury L, Brophy S, Milicic A, et al. Wholegenome screening in ankylosing spondylitis: evidence of non-MHC geneticsusceptibility loci. Am J Hum Genet 2000;68:918-26.

18 Arbour NC, Lorenz E, Schutte BC, Zabner J, Kline JN, Jones M, et al. TLR4 mutations are associated with endotoxin hyporesponsiveness in humans. Nat Genet 2000;25:187-91
19 Erridge C, Stewart J, Poxton IR. Monocytes heterozygous for the Asp299Gly and Thr399lle mutations in the Toll-like receptor 4 gene show no deficit in lipopolysaccharide signaling. J Exp Med 2003;197:1787-91.

20 von Aulock S, Schroder NW, Gueinzius K, Traub S, Hoffmann S, Graf K, et al. Heterozygous toll-like receptor 4 polymorphism does not influence lipopolysaccharide-induced cytokine release in human whole blood. J Infect Dis 2003; 188:938-43.

21 van der Linden S, Valkenburg HA, Cats A. Evaluation of diagnostic criteria for ankylosing spondylitis: a proposal for modification of the New York criteria. Arthritis Rheum 1984;27:361-8.

22 Morré SA, Murillo LS, Spaargaren J, Fennema HS, Peña AS. The role of the toll-like receptor 4 Asp299Gly polymorphism in the susceptibility to Candida albicans infection. J Infect Dis 2002;186:1377-9.

23 Taurog JD, Richardson JA, Croft JT, Simmons WA, Zhou M, FernandezSueiro $\mathrm{JL}$, et al. The germfree state prevents development of gut and joint inflammatory disease in HLA-B27 transgenic rats. J Exp Med 1994; 180:2359-64.

24 Palm O, Moum B, Ongre A, Gran JT. Prevalence of ankylosing spondylitis and other spondyloarthropathies among patients with inflammatory bowel disease: a population study (the IBSEN study). J Rheumatol 2002;29:51 1-15.

25 Mielants H, Veys EM. The bowel and spondylarthritis: a clinical approach. In: Calin A, Taurog JD, eds. The spondylarthritides, 1st ed. Oxford: Oxford University Press, 1998: 129-57.

26 Baeten D, De Keyser F, Van Damme N, Veys EM, Mielants H. Influence of the gut and cytokine patterns in spondyloarthropathy. Clin Exp Rheumatol 2002;20(suppl 28):S38-42.

27 Baeten D, De Keyser F, Mielants H, Veys EM. Ankylosing spondylitis and bowel disease. Best Pract Res Clin Rheumatol 2002;16:537-49.

28 Peña AS. Genetics of inflammatory bowel diseases: past, present, and future. Dig Dis 2003;21:85-90.

29 Hoffman IE, Demetter P, Peeters M, De Vos M, Mielants H, Veys EM, et al. Anti-saccharomyces cerevisiae $\lg A$ antibodies are raised in ankylosing spondylitis and undifferentiated spondyloarthropathy. Ann Rheum Dis 2003;62:455-9.

30 Hugot JP, Chamaillard M, Zouali H, Lesage S, Cezard JP, Belaiche J, et al. Association of NOD2 leucine-rich repeat variants with susceptibility to Crohn's disease. Nature 2001;411:599-603.

31 Ogura Y, Bonen DK, Inohara N, Nicolae DL, Chen FF, Ramos R, et al. A frameshift mutation in NOD2 associated with susceptibility to Crohn's disease. Nature 2001;411:603-6.

32 Hampe J, Cuthbert A, Croucher PJP, Mirza MM, Mascheretti S, Fisher S, et al. Association between insertion mutation in NOD2 gene and Crohn's disease in German and British populations. Lancet 2001;357:1925-8.

33 Murillo L, Crusius JBA, van Bodegraven AA, Alizadeh BZ, Peña AS. CARD15 gene and the classification of Crohn's disease. Immunogenetics 2002:54:59-61.

34 van der Paardt M, Crusius JBA, de Koning MH, Murillo LS, van de Stadt RJ, Dijkmans BA, et al. CARD15 gene mutations are not associated with ankylosing spondylitis. Genes Immun 2003:4:77-8.

35 Ferreiros-Vidal I, Amarelo J, Barros F, Carracedo A, Gomez-Reino JJ, Gonzalez A. J. Lack of association of ankylosing spondylitis with the most common NOD2 susceptibility alleles to Crohn's disease. J Rheumatol 2003;30:102-4

36 Crane AM, Bradbury L, van Heel DA, McGovern DP, Brophy S, Rubin L, et al. Role of NOD2 variants in spondylarthritis. Arthritis Rheum 2002;46:1629-33

37 Beutler BA. The role of tumor necrosis factor in health and disease. J Rheumatol, 1999;26 Suppl 57, 16-21.

38 Beutler BA. Autoimmunity and apoptosis: the Crohn's connection. Immunity 2001;15:5-14.

39 Vercelli D. Learning from discrepancies: CD14 polymorphisms, atopy and the endotoxin switch. Clin Exp Allergy 2003;33:153-5. 